ENTREPRENEURSHIP AND SUSTAINABILITY ISSUES

ISSN 2345-0282 (online) http://jssidoi.org/jesi/

2021 Volume 8 Number 3 (March)

http://doi.org/10.9770/jesi.2021.8.3(31)

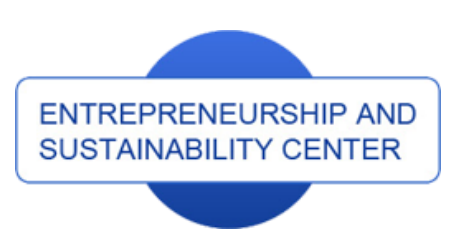

Publisher

http://jssidoi.org/esc/home

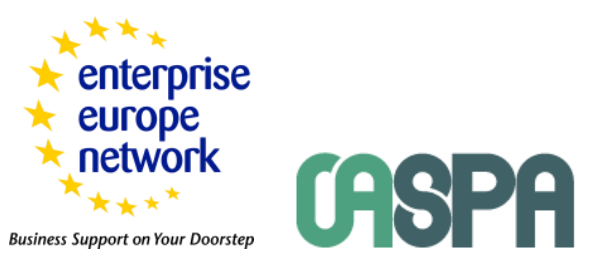

Business Support on Your Doorstep

\title{
MEASURING EFFICIENCY BY USING SELECTED DETERMINANTS IN REGIONAL SMEs*
}

\author{
Ladislav Mura ${ }^{1 *}$, Zuzana Hajduová ${ }^{2}$ \\ ${ }^{1}$ Pan-European University, Faculty of Economics and Business, Tematinska 10, 85105 Bratislava, Slovakia \\ ${ }^{2}$ University of Economics, Faculty of Business Management, Dolnozemská cesta 1/b, 85235 Bratislava, Slovakia \\ E-mails:*1 ladislav.mura@gmail.com (corresponding author); 2 zuzana.hajduova@euba.sk
}

Received 15 August 2020; accepted 28 January 2021; published 30 March 2021

\begin{abstract}
In comparison to other EU countries, Slovakia is characterized by increased business activity and the highest representation of micro-enterprises in the business sector. In the years 2017/2018 -, up to 75\% of companies in the SME segment conducted business activity in the field of industry, accommodation, trade, transport and construction. The collected data clearly indicates a growing trend in providing accommodation services, business and information services, business and brokerage services. The main objective of the study is to assess the sectorial structure of SMEs and managerial determinants of their efficiency. The research sample of the enterprises has shown that even these methods can better warn against bankruptcy by predicting whether business will or will not be sustainable. In comparison to EU-28, Slovakia has a significantly higher representation of industry and civil engineering in the sectoral structure of SMEs, while the service sector is under-represented. We conducted a research focusing on our defined area of business in the SME segment. The evaluation of efficiency is most often performed by ratios, which are based on current financial statements of companies. The disadvantage of these measurements is the focus on a certain quantified range of parameters that do not significantly affect the overall efficiency of the unit. Based on the DEA methodology, a selected segment of services in individual regions of Slovakia was analysed in details. The SME sector in individual regions of Slovakia is showing differences. This work presents the results of the clearly defined efficiency of business entities. The main part of this work is about the exact determination of factors that need to be changed in order the specified entity shows signs of efficient management
\end{abstract}

Keywords: small and medium enterprises; regions; DEA; models; correlation

Reference to this paper should be made as follows: Mura, L., Hajduová, Z. 2021. Measuring efficiency by using selected determinants in regional SMEs. Entrepreneurship and Sustainability Issues, 8(3), 487-503. http://doi.org/10.9770/jesi.2021.8.3(31)

JEL Classifications: C14, C44, C61, L21

\footnotetext{
* This research was supported by the project VEGA 1/0813/19 Managing the development of innovative and start-up forms of businesses in international environment and verification of INMARK concept, which has received funding from Ministry of Education, Science, Research and Sport of the Slovak Republic and project GAAA 5-5/2020 Development of family businesses in Slovak regions, which has received funding from Grant Agency Academia aurea.
} 
ENTREPRENEURSHIP AND SUSTAINABILITY ISSUES

ISSN 2345-0282 (online) http://jssidoi.org/jesi/

2021 Volume 8 Number 3 (March)

http://doi.org/10.9770/jesi.2021.8.3(31)

Make your research more visible, join the Twitter account of ENTREPRENEURSHIP AND SUSTAINABILITY ISSUES: @Entrepr69728810

\section{Introduction}

One of the most important discussions of scientific literature is related to the factors that determine the efficiency SMEs, analyzing different specific factors and selected determinants SMEs. Only the precisely processed and evaluated data are helpful to address the issue of business development in the SME sector. Identifying the factors that cause this segment to have a competitive advantage is a high research priority. Differences need to be identified and the determinants of low economic performance in all regions of our country has to be removed (Dellis et al. 2016; Lambert 2017; Selivanova-Fyodorova et al., 2019; Chehabeddine \& Tvaronavičiené, 2020). There are several studies available in the scientific literature that are addressing the issue of SMEs. There are different approaches about the definition and characteristics of SMEs. There are also numerous criteria either qualitative or quantitative to decide what form of enterprise we talk about. Undoubtedly, we can say that these forms of businesses are an important element of the market that cannot be replaced by large companies due to their robustness (Anyakoha, 2019; Chunling, 2019; Hudáková \& Masár, 2018). SMEs form the basis of a market economy, employment, added value or international trade, and are a prerequisite for stable growth of the global economy (Zauskova, Reznickova, 2020; Cooper, 2017; Peracek, et al., 2017; Chrenekova et al., 2016; Csikosova, Culkova, 2012). They are a strategic source of jobs that create entrepreneurship, especially at regional level and contribute to innovation in the EU, therefore the most important entities promoting competitiveness, employment and business efficiency (Harabi, 2005; Kordos, 2018; Poór et al., 2020; Dvorský et al., 2020).

Considering further scientific studies and literature, our ambition is to focus on firm-specific factors potentially influencing efficiency. The aim of our study is to identify the influence of the selected efficiency factors in the SME sector. The choice of specific sector orientation is motivated by the effort to capture individual effects on efficiency. The paper is organized as follows: presents literature review on the topic connected with measuring efficiency determinants of firms: introduce data and methodology: assess empirical results and their discussion within conclusions.

\section{Theoretical background}

Several research studies emphasize the importance of measuring the effectiveness and evaluating the degree of innovation performance of SMEs (Brocki, 2019; Meyer, Kot, 2019). The influence of institutional factors on ensuring the innovative performance of SMEs deserves attention. SMEs have become an important field of research in the last years of our century (European Commission, $2016 \mathrm{a}, \mathrm{b}$ ). The aim of this research is to reveal the influence of orientation on the interaction of individual inputs and the effective operation of companies in the service sector (European Commission, 2017). Business development is very important in terms of macroeconomic development of the state (Janoskova, Culkova, Csikosova, 2018). This has an impact on GDP and reducing the number of unemployed in regions showing weak economic performance (Cepel, 2020, Remeikiene et al., 2020; Haviernikova et al., 2019; Cera, 2019). We define the performance of SMEs primarily in quantitative terms. Factors with a direct impact affect the results in the field of finance, quality of production, revenue increase, reduction of costs, increase in profits, company liquidity and stock levels (Huggins,2015; Raisová, Regásková, \& Lazányi, 2020; Zavadska, Zavadsky, 2020). The previous factors focus on quantitative assessment of companies, but the qualitative aspect is also important, such as setting and meeting the company's strategic goal, potential customer satisfaction, innovation, but also product and service promotion and marketing development (Pisar, 2019; Lakner, 2018). 


\section{ENTREPRENEURSHIP AND SUSTAINABILITY ISSUES}

ISSN 2345-0282 (online) http://jssidoi.org/jesi/

2021 Volume 8 Number 3 (March)

http://doi.org/10.9770/jesi.2021.8.3(31)

Make your research more visible, join the Twitter account of ENTREPRENEURSHIP AND SUSTAINABILITY ISSUES: @Entrepr69728810

The scientific literature mentions a wide range of environmental factors potentially influencing the performance of SMEs. An increased attention is paid to a stable size of the business (Vekic, 2020; Belas et al., 2020; Gupta, 2016; Virglerová et al., 2017; Kotaskova, Rozsa, 2018; Dyduch, 2019), business staff and human resources practices, sales networks, products, processes, marketing innovations, as well as the sustainable management (Kotulic et al., 2017; Lazikova et al., 2018; Tingvall, 2018; Durda \& Kljucnikov, 2019). Exports, market orientation and planning flexibility have been identified as priorities in SME studies in terms of transformation into efficient economic units (Sheehan, 2013; Bencikova, Mala, Minarova, 2013; Wallsten, 2000; Jašková, 2019; Dvorský, et al. 2019). Sustainable development in the field of services is closely related to the level of business development in the country (Kozubíková \& Kotásková, 2019). Our government targeted to develop this segment (Horvath and Machyniak, 2016; Cibik, and Melus, 2019). It is backed by the existence of a relatively wide range of institutions, which focus exclusively or at least to some extent on supporting policies to create a favorable business environment for small businesses (Altuntas, 2018; Tamulevičiene, 2020).

Sustainability entrepreneurship is directly related to the financial situation of the enterprise (Cvetanovič et al., 2014). The importance of factors enhancing the firm's efficiency was initially discussed in the work of Wernerfelt (1984) and later significantly developed by Barney (1991). The size of SME proved to have no impact on the efficiency. Most works have proved that larger businesses generate higher profits and thus showed positive relation between the size and business performance (Pratheepan, 2014). On the other hand, some studies found evidence of a negative size-profitability relationship. In order to maintain the market position and competitiveness, companies must constantly adapt to market changes, whether it is a change in consumer preferences or in the behavior of competitors. Thus, the competitiveness of enterprises is affected by a numerous of factors, which affect the efficiency of business.

The evaluation of efficiency is most often performed using financial indicators, which are based on parameters from financial and annual reports on the management of the company (Mikhaylova, 2019). The disadvantage of these measurements is the focus on a certain number of financial factors that assess the overall effectiveness of the examined business units insufficiently. We used the quantitative DEA method for this assessment (Fernandes, 2018; Wei, 2012).

\section{Research objective and methodology}

DEA methodology is the selection of the investigated units from the aspect of their efficiency. The unit is efficient when it consumes a small number of inputs, while generating a large number of outputs. Data wrapping method is an optimization method classified as a method of multicriteria decision-making. In comparison to statistical models, comparing units with respect to average efficiency, DEA is based on the theory of linear programming. When evaluating the effectiveness of units, it is necessary to introduce a hypothetical (virtual) unit, which is characterized as a weighted average of effective units. A hypothetical unit becomes the basis for evaluating real units. A real unit will be inefficient if it produces fewer outputs or consumes more inputs than the hypothetical unit. Sometimes it is difficult to identify common units, which involve various inputs and outputs. The DEA method generalizes the calculation of the relative efficiency rate and allows different weights of input determinants and output determined key factors for individual units of the model. These weight values are not connected to price but to item technology, and the term of relative technical efficiency is used. The DEA model is considered an important management tool for determining efficiency. The basic task is to compare organizational units within a certain specified reference group. 
Make your research more visible, join the Twitter account of ENTREPRENEURSHIP AND SUSTAINABILITY ISSUES: @Entrepr69728810

The DEA methodology has the principle of comparing inputs and outputs. Accordingly, we distinguish models focusing on these aspects, where influence directly interferes with management of the surveyed company or operation. In general, efficiency is expressed as a ratio of the output values to the input values. Its value is considered to be less than or equal to 1 . The mentioned ratio of output and input units expresses the value of the efficiency of the units. Relative efficiency DMUj, $\mathrm{j}=1, \ldots, \mathrm{n}$ are defined as a function of the determined factors as follows (Simar, 2007; Ramanathan, 2011):

$$
E_{j}(u, v)=\frac{y_{j u}^{T}}{x_{j}^{T} v}
$$

$$
E=\left\{\mathrm{DMUj} \| E_{j}(u, v)=1 ; j=1,2, \ldots \ldots, n\right\}
$$

Assuming we have $\mathrm{m}$ input items and s output items, we have determined individual $D M U j$ from a set of $\mathrm{n}$ units we will record input data $(x 1 j, \ldots, x m j)$ in the matrix $\mathrm{X}$ and output data $(y 1 j, \ldots, y s j)$ in the matrix $\mathrm{Y}$. Then it has matrix X size ( $\mathrm{m} \mathrm{x} \mathrm{n)}$ and matrix Y size (s x n) (Charnes, 1984; Mardani, 2017):

$$
\begin{gathered}
X=\left[x_{1}, x_{2}, x_{3}, \ldots \ldots \ldots, x_{n}\right]=\left[\begin{array}{ccc}
x_{1} & \ldots & x_{n} \\
\vdots & \ldots & \vdots \\
x_{m 1} & \ldots & x_{m n}
\end{array}\right] \\
Y=\left[y_{1}, y_{2}, y, \ldots \ldots \ldots, y_{n}\right]=\left[\begin{array}{ccc}
y_{1} & \ldots & y_{n} \\
\vdots & \ldots & \vdots \\
y_{s 1} & \ldots & y_{s n}
\end{array}\right]
\end{gathered}
$$

Purpose function: $\quad \max _{v, u} \theta=\frac{u_{1} y_{10}+\cdots \ldots \ldots \ldots+u_{s} y_{s o}}{v_{1} x_{10}+\cdots \ldots \ldots \ldots+v_{m} x_{m o}}$

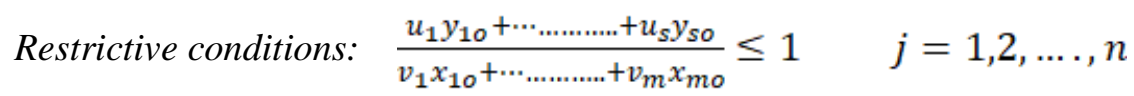

Non-negative condition $\quad v_{1}, \ldots \ldots \ldots v_{m} \geq 0 ; u_{1}, \ldots \ldots \ldots u_{s} \geq 0$ 
Make your research more visible, join the Twitter account of ENTREPRENEURSHIP AND SUSTAINABILITY ISSUES: @Entrepr69728810

CCR DEA model - input-oriented CCR model based on standardization of the value of $x_{-} j^{\wedge} T v=1$ assesses the efficiency of units.

The DMUj is considered to be effective in the case $E_{-} j\left(\left(u_{-}(j),\right) \hat{,},\left(v_{-}(j,)^{\wedge}\right)=1\right.$ and $u>0, v>0$. The use of declared conditions is justified by the type of tasks, because each task aims to maximize the efficiency of the DMU. Zero price means that the given input or output is neglected. If these zero prices suppress unfavourable inputs or outputs, the DMU can become effective.

$$
\begin{gathered}
\max _{u \in R_{+,}^{p} v \in R_{+,}^{m}} Y_{j}^{T} u-X_{j}^{T} v \\
Y_{j}^{T} u-X_{j}^{T} v \leq 0 \\
u \geq 1, v \geq 1
\end{gathered}
$$

The BCC DEA input model also focuses on a detailed analysis of inputs, with both positive and negative trends. The model is the following (Tsai, 2016):

$$
\begin{gathered}
\min _{\theta, \lambda, s, e} \theta-\epsilon\left(1^{T} s+1^{T} e\right) \\
Y \lambda-s=Y_{j} \\
-X \lambda+\theta X_{j}-e=0 \\
1^{T} \lambda=1 \\
\lambda \geq 0, e \geq 1, s \geq 0
\end{gathered}
$$

The result of solving problems " $n$ ", but not necessarily " $n$ " different levels, since the level that belongs to the effective DMUj may be the closest level for any with inefficient DMUj. The input CCR and BCC models assume total independence of the inputs (or outputs), so the input (or output) of any given DMU does not affect the input (or output) of other units.

\section{Results and discussion}

The SME segment has its own precisely defined rules for the inclusion of companies in a given structure. The relevant data are very important. We can state that there were 542,525 active business entities in our country at the time of the research. The sectoral structure is presented in Figure 1. After 2010, the development of the number of micro-enterprises has stabilized and currently reaches almost $96,8 \%$ of the total number of active entities. The relationship between small businesses and large development companies is in favor of doing business in small businesses. The trend is a 3\% annual increase. The growth rate of large companies leveled off. 
Make your research more visible, join the Twitter account of ENTREPRENEURSHIP AND SUSTAINABILITY ISSUES: @Entrepr69728810

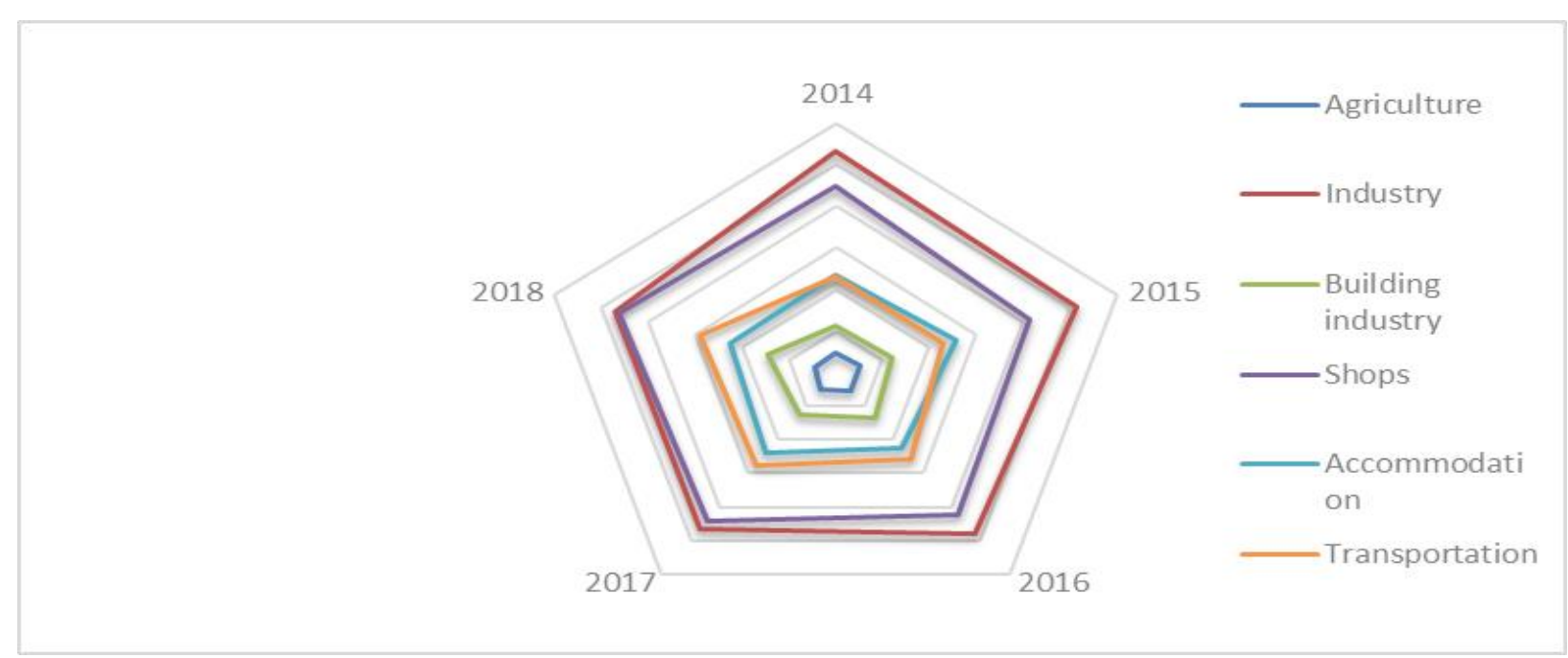

Figure 1. Sectoral structure

Source: own processing

The research conducted focused on processing statistical data of eight regions in Slovakia. We will use the following abbreviations for each region: Bratislava region (BA), Trnava region (TR), Trenčín region (TN), Nitra region (NI), Žilina region (ZA), Banská Bystrica region (BB), Prešov region (PO), Košice region (KE). Almost one fifth of the SMEs $(19.0 \% ; 106,643$, respectively) carried out their main business activity in trade sector. This is followed by the construction sector, where representation of SMEs was $17.0 \%(95,315)$. A total of 76,454 SMEs performed their main activity in the industrial sector, which represents a share of $13.7 \%$. Approximately, every fifth active small and medium-sized enterprise can be found in BA region. In other regions, the representation of SMEs is lower (Table 1.). After the BA region, most of the surveyed companies are concentrated in the ZA region. Their ratio reached $13.69 \%$. TN region is the lowest represented by SMEs. The most significant drop in the number of SMEs by $3.09 \%$ was recorded in BA region. In absolute terms, this represents a decrease of 3,898 business entities. In the case of other regions, the number of SMEs decreased by $1.1 \%$ to $2.4 \%$ annually. The number of SMEs increased only in PO region by $2.2 \%$, and ZA region by $0.5 \%$.

Table 1. Number of business entities by region

\begin{tabular}{|c|c|c|c|c|}
\hline Regions of SR & Micro-enterprises & Small enterprise & $\begin{array}{l}\text { Medium } \\
\text { enterprise }\end{array}$ & Large enterprises \\
\hline Bratislava region (BA) & 73022 & 3342 & 895 & 225 \\
\hline Trnava region $(\mathrm{TR})$ & 18862 & 1299 & 273 & 60 \\
\hline Trenčín region $(\mathrm{TN})$ & 16381 & 1325 & 303 & 91 \\
\hline Nitra region $\quad(\mathrm{NI})$ & 22561 & 1498 & 346 & 65 \\
\hline Žilina region $\quad(\mathrm{ZA})$ & 21939 & 1587 & 329 & 75 \\
\hline Banská Bystrica $(\mathrm{BB})$ region & 19406 & 1179 & 252 & 52 \\
\hline
\end{tabular}


ENTREPRENEURSHIP AND SUSTAINABILITY ISSUES

ISSN 2345-0282 (online) http://jssidoi.org/jesi/

2021 Volume 8 Number 3 (March)

http://doi.org/10.9770/jesi.2021.8.3(31)

Make your research more visible, join the Twitter account of ENTREPRENEURSHIP AND SUSTAINABILITY ISSUES: @Entrepr69728810

\begin{tabular}{|l|l|l|l|l|}
\hline Prešov region (PO) & 19343 & 1468 & 284 & 56 \\
\hline Košice region (KE) & 21948 & 1364 & 258 & 55 \\
\hline Total & $\mathbf{2 1 3 4 6 2}$ & $\mathbf{1 3 0 6 2}$ & $\mathbf{2 9 4 0}$ & $\mathbf{6 7 9}$ \\
\hline
\end{tabular}

Source: our processing

There are 122,576 active SMEs registered in BA region. Micro-enterprises accounted for 96.39\%, which represent the lowest share of all regions of the Slovak Republic (Hudáková et al., 2017; Haviernikova et al., 2018; Peracek, 2019). Small enterprises accounted for 2.69\%, and the least represented were the medium-sized enterprises with $0.69 \%$. The attractiveness of BA region for large companies is confirmed by high representation of small, medium and large companies compared to the size structure of companies at national level. The largest concentration of SMEs was recorded in Bratislava district (22.2\%). The service sector has a high importance in Slovakia, since it can be considered as a key to tourism sector development. The volume of revenues in tourism sector produced by SMEs reached 22\%, while this ratio was $9 \%$ in the case of self-employed. Based on the assumption of economic growth in Slovakia, development of services sector is a priority. The volume of revenues in this sector accounts for up to $85 \%$ of the total volume of profits in the small and medium-sized enterprises segment. We focused on companies that provide accommodation in individual regions. The efficiency of these facilities would bring increase in tourism activities and employment in tourism sector of Slovakia. Today, this segment is characterized by low labor productivity and low qualification of employees in the sector. The employment in this segment is presented in Figure 2., according to years and regions.

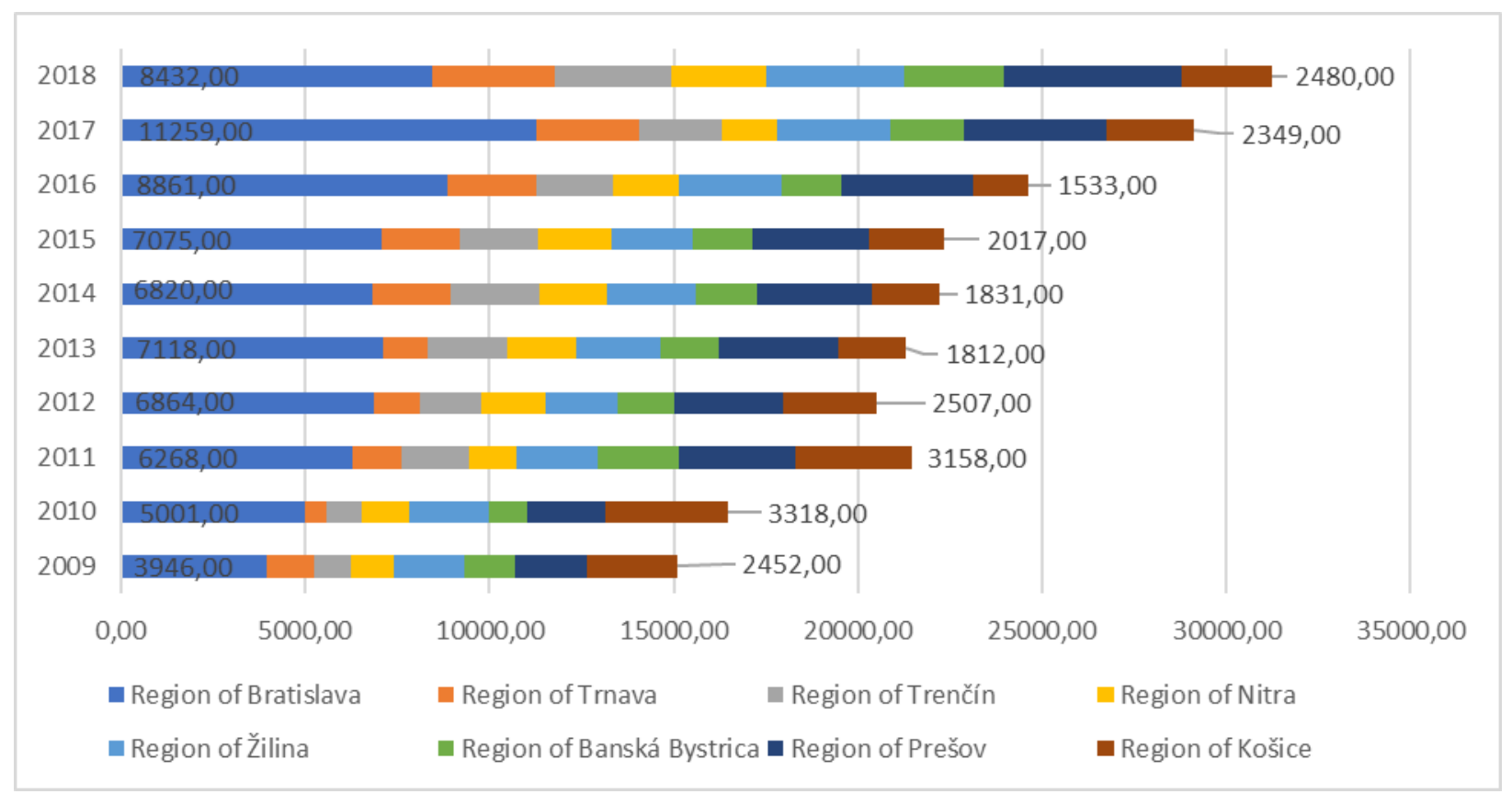

Figure 2. Share of employment in the accommodation and services segment Source: own processing 
ENTREPRENEURSHIP AND SUSTAINABILITY ISSUES

ISSN 2345-0282 (online) http://jssidoi.org/jesi/

2021 Volume 8 Number 3 (March)

http://doi.org/10.9770/jesi.2021.8.3(31)

Make your research more visible, join the Twitter account of ENTREPRENEURSHIP AND SUSTAINABILITY ISSUES: @Entrepr69728810

\section{Efficiency model}

During the efficiency assessment of the particular segment within the regions, we chose the suitable DMU units from each region. It was a sample of 34 accommodation units, which we randomly selected from different regions of Slovakia. We examined the sample over a period of six years (2014-2019).

We made 204 observations, which were analyzed in terms of time series. From each region, We selected and compared five accommodation facilities characterized by the same parameters from individual regions of Slovakia. We achieved to maintain the homogeneity of the individual DMUs. The next step in the implementation was to determine the inputs and outputs for the DEA methodology in order to calculate the efficiency. The trend in our segment is to increase outputs, while maintaining the same inputs, or to increase outputs when decreasing inputs. We have chosen the following parameters as input parameters: employees, receivables, total assets. As output variables, we determined the following: restaurant revenues, equity, accommodation revenues. For clarity, we named the individual DMUs by regions and serial number. We marked the researched accommodation facilities by regions.

Based on these data, efficiency can be calculated using DEA CCR models, which assume that subjects have constant revenues of scale, and DEA BCC, which assumes variable revenues of the scale as the efficiency limit is not linear for BCC, can envelop more DMUs. Thus, the results of the efficiency measurement according to the DEA BCC model are better. The DEA CCR and DEA BCC models can be further divided into input and output. The input model is focusing on minimizing inputs at a given volume of outputs; the output model on maximizing outputs at a given volume of inputs. It should be emphasized that the resulting values of input and output efficiency are inverse values. If we want to explain the efficiency values using a regression model, it is necessary to determine these explanatory variables, which could be the determinants of the efficiency calculated in the first step. The second step is the actual implementation of the regression model. Therefore, such an approach is called a two-step DEA. Table 2. shows the basic characteristics of possible determinants of the efficiency of accommodation units.

Table 2. Basic statistical indicators for a set of possible determinants of efficiency

\begin{tabular}{|c|c|c|c|c|c|}
\hline Indicator & $\begin{array}{l}\text { Customer } \\
\text { evaluation }\end{array}$ & $\begin{array}{l}\text { Capital- } \\
\text { Ownership }\end{array}$ & $\begin{array}{r}\text { Accommodation } \\
\text { category }\end{array}$ & $\begin{array}{l}\text { Business } \\
\text { time period }\end{array}$ & Region of SR \\
\hline $\mathbf{N}$ & 204.00 & 204.00 & 204.00 & 204.00 & 204.00 \\
\hline Min & 71.00 & 1.00 & 1.00 & 6.00 & 1.00 \\
\hline Max & 96.00 & 3.00 & 2.00 & 35.00 & 3.00 \\
\hline Standard deviation & 0.51 & 0.85 & 0.46 & 14.12 & 0.80 \\
\hline Average & 83.51 & 2.11 & 1.33 & 20.52 & 2.00 \\
\hline
\end{tabular}


ENTREPRENEURSHIP AND SUSTAINABILITY ISSUES

ISSN 2345-0282 (online) http://jssidoi.org/jesi/

2021 Volume 8 Number 3 (March)

http://doi.org/10.9770/jesi.2021.8.3(31)

Make your research more visible, join the Twitter account of ENTREPRENEURSHIP AND SUSTAINABILITY ISSUES: @Entrepr69728810

The input efficiency values are in the closed interval 0 to 1 . The output efficiency values are in the left closed interval 1 to infinity. The DMU is effective if its efficiency is equal to 1 for both models.

Table 3. shows the results of the DEA models for the whole sample of accommodation facilities during the research period.

Table 3. Basic statistical indicators efficiency of DEA models

\begin{tabular}{|c|c|c|c|c|c|c|c|}
\hline Variable & Average & $\begin{array}{c}\text { Standard } \\
\text { deviation }\end{array}$ & Spread & Min & Max & $\begin{array}{c}\text { Lower } \\
\text { 95\% int. of } \\
\text { reliability }\end{array}$ \\
$\begin{array}{c}\text { 95\%- int. of } \\
\text { reliability }\end{array}$ \\
\hline CCR output model & 0.8915 & 0.1311 & 0.0253 & 0.6384 & 1.0000 & 0.8795 & 0.9212 \\
\hline BCC input model & 0.9621 & 0.0911 & 0.0191 & 0.6232 & 1.0000 & 0.9454 & 0.9684 \\
\hline CCR output model & 1.1231 & 0.0944 & 0.0430 & 1.0000 & 1.7895 & 1.1819 & 1.1843 \\
\hline BCC output model & 1.0930 & 0.1093 & 0.0126 & 1.0000 & 1.5846 & 1.0549 & 1.0890 \\
\hline
\end{tabular}

Source: our processing

The average value of our sample in the case of input CCR model is 0.89 , while the value in the case of BCC of the input model is approximately 0.96. If we would like to determine the extent average of the basic set with a probability of $95 \%$, it can be said that for CCR efficiency will be an interval of 0.88 to 0.92 . In the case of the BCC model, it will be 0.95 to 0.97 , which are relatively good values. However, it should be emphasized that these are average values, the lowest efficiency achieved in the case of the CCR of the input model was 0.62 and in the case of the BCC model 0.64.

Our study provided the statistically significant impact of some determinants, namely evaluation of customers, ownership-capital, category of accommodation, length of conducting business, region. Thus, we can agree with Grasserová et al. (2012) that the variable of efficiency depending on the determinants is used to measuring. Our findings can be explained by several arguments.

In this chapter, we will deal with the evaluation of the effects of individual determinants of the efficiency of accommodation units. Based on the performed analysis, we used the double bootstrap methodology. The purpose of this methodology is that the dependent variable becomes a variable of a stochastic nature. We applied truncated regression to the achieved results. The results are summarized in Table 4. 
ENTREPRENEURSHIP AND SUSTAINABILITY ISSUES

ISSN 2345-0282 (online) http://jssidoi.org/jesi/

2021 Volume 8 Number 3 (March)

http://doi.org/10.9770/jesi.2021.8.3(31)

Make your research more visible, join the Twitter account of ENTREPRENEURSHIP AND SUSTAINABILITY ISSUES: @ Entrepr69728810

Table 4. Summary results

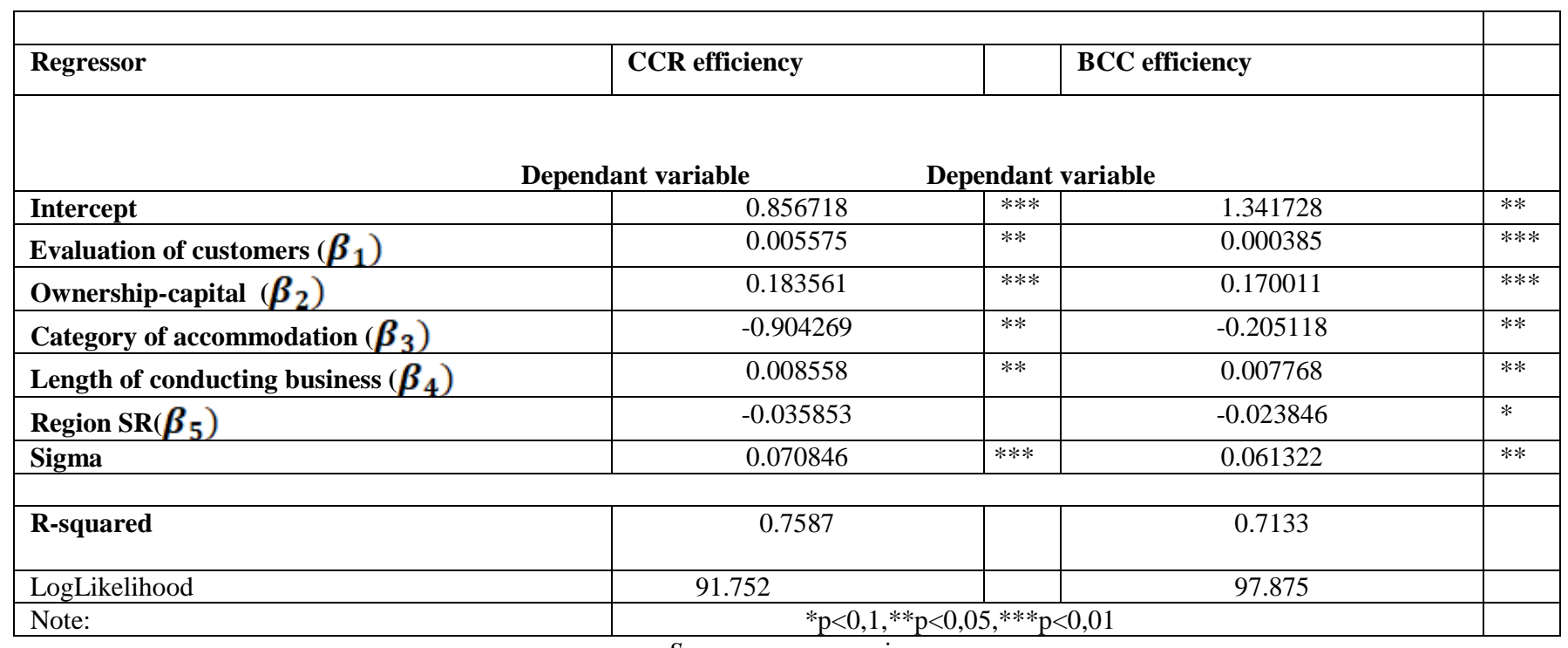

Source: our processing

From the point of view of the influence of individual factors on efficiency of accommodation facility, the following findings can be observed in both models. Reviews of accommodated guests are very important. The evaluation of customers has a positive effect, so increasing the positive evaluation, the efficiency of the accommodation facility also increases. This indicator acquires greater significance in both BCC models (Figure 3.). Ownership - the variable 1 in resampling expresses purely domestic ownership and 3 expresses purely foreign ownership. The higher value tends to increase efficiency faster, and therefore we state that accommodation facilities with solely foreign ownership are more efficient than accommodation facilities $100 \%$ or in a certain proportion owned by domestic and foreign owner. The variable is statistically significant in both models at the significance level of 0.01 . The category of accommodation facility is a factor, where value 1 is indicating a guesthouse, while value 2 refers to hostels. If this variable has a negative effect, it can be said that a lower value will reduce efficiency less, which means that guesthouses are more efficient than tourist hostels. The predictive ability of the model is higher in the case of the BCC model based on the Log likelihood and R-squared indicators, while this model describes $71.33 \%$ of the variability of the basic set. The main part of our research is to build a model for the efficiency of accommodation units.

$$
\begin{gathered}
\text { model }=1.341728+0,000385 * \beta_{1}+0,170011 * \beta_{2}-0,205118 * \beta_{3}+0,007768 * \beta_{4} \\
-0,023846 * \beta_{5}+\varepsilon
\end{gathered}
$$

The evaluation model that is the outcome of this research, especially in the form of implementing in practice can be an excellent tool for a more objective evaluation of the effectiveness of the surveyed business entities. It is an objective method, and can be used to measure business entities. 
Make your research more visible, join the Twitter account of ENTREPRENEURSHIP AND SUSTAINABILITY ISSUES: @ Entrepr69728810
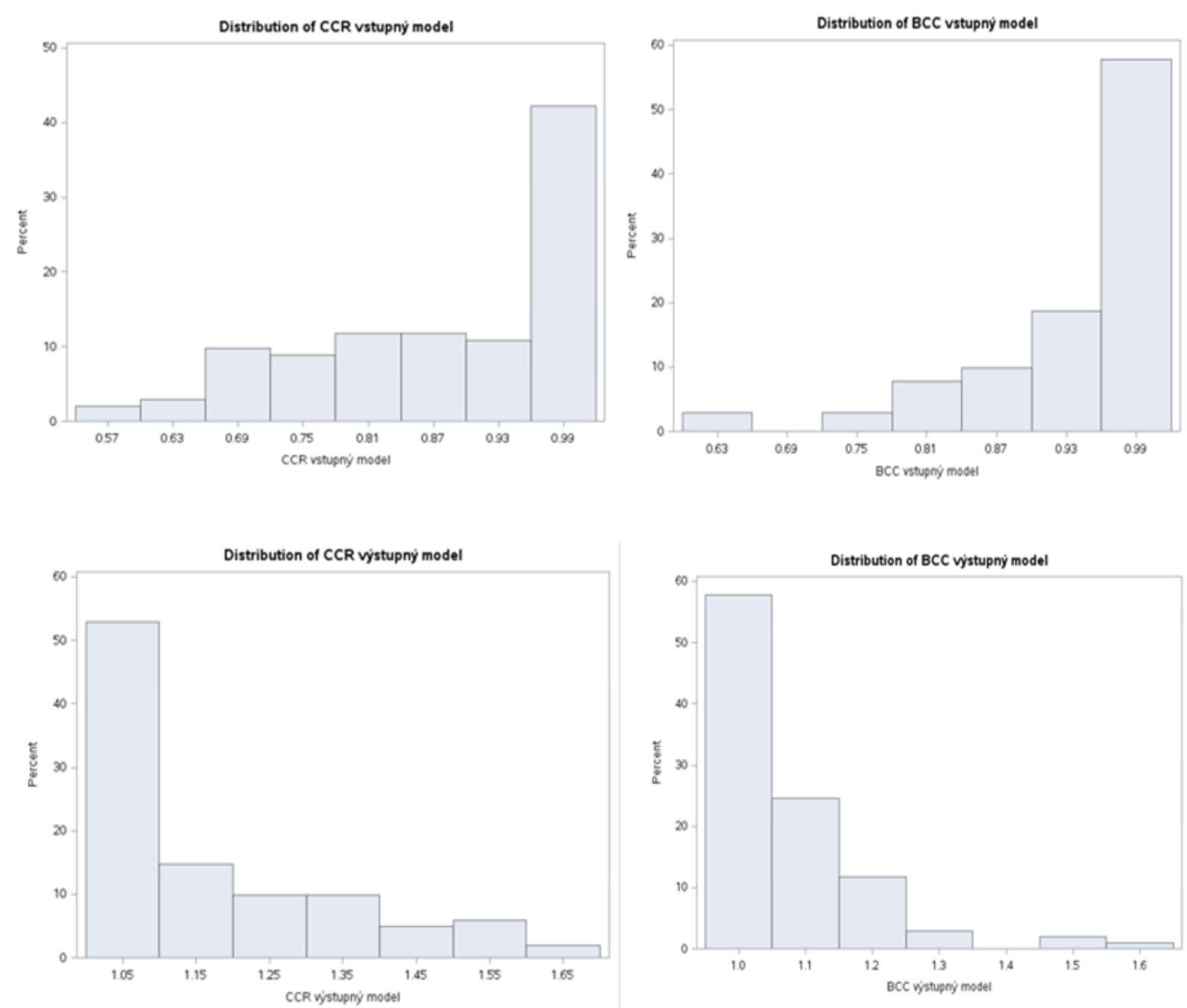

Figure 3. Histogram of the distribution of the efficiency frequency

Source: our processing

In the context of services, efficiency is understood very similarly and to achieve it, it is necessary to achieve the desired effect, which is measurable. A study by Haber and Reichel (2005) focused on finding current performance measures more specifically in accommodation services companies, which identified 26 performance indicators. The provision of accommodation services often enters the saturation phase (Doležal et.al, 2000) and it requires the experts to address the sustainable model of these business units. 


\section{ENTREPRENEURSHIP AND SUSTAINABILITY ISSUES}

ISSN 2345-0282 (online) http://jssidoi.org/jesi/

2021 Volume 8 Number 3 (March)

http://doi.org/10.9770/jesi.2021.8.3(31)

Make your research more visible, join the Twitter account of ENTREPRENEURSHIP AND SUSTAINABILITY ISSUES: @Entrepr69728810

\section{Conclusions}

In the current era of globalization it is very important to look at the discussed issue in terms of economic growth. In order to fulfil the main aim of the study, analysis with fixed effects models was applied on a sample of 34 accommodation units, covering the period from 2014 to 2019. The results of the conducted analysis supported the hypothesis that a country like Slovakia must set itself the primary goal of revealing hidden reserves in the segment of services provided. In the last six years, up to about $83 \%$ of new jobs have been created in this segment. This research focused on the area of services on regional scale in Slovakia. Using the implementation of the DEA method, and individual models focusing on inputs, we were able to identify the inefficient units in the field. As an output of our research, we want to emphasize that each inefficient unit, we were able to accurately quantify need to be changed with respect to the efficiency of the processes that take place in it. Knowing the degree of efficiency or inefficiency will help to identify the weaknesses of the production unit and at the same time will help to identify the shortcomings that affect the economic result of the company.

The results of our study provide guidelines for managers of Slovak companies to understand how to run their small businesses in the SME segment effectively. Our model points to the factors that affect the efficiency of business as much as possible.

\section{References}

Ajaz Khan, K., Çera, G., \& Nétek, V. (2019). Perception of the Selected Business Environment Aspects by Service Firms. Journal of Tourism and Services, 10(19), 111-127. https://doi.org/10.29036/jots.v10i19.115

Altuntas, S., Cinar, O., \& Kaynak, S. (2018). Relationships among advanced manufacturing technology, innovation, export, and firm performance: Empirical evidence from Turkish manufacturing companies. Kybernetes, 47(9), 1836. https://doi.org/10.1108/K-10-2017$\underline{0380}$

Anyakoha, C. (2019). Job analysis as a tool for improved organizational performance of SMEs in Lagos, Nigeria. Central European Journal of Labour Law and Personnel Management, 2 (1), 7-16. https://doi.org/10.33382/cejllpm.2019.02.0

Barney, J.B. (1991). Firm resources and sustained and sustained competitive advantage. Journal of Management, 17(1), 99-120.

Belas, J., Gavurova, B., Kubalek, J., \& Kubak, M. (2020). Discrepancies in perception and evaluation of macroenvironment - sectoral analysis. Journal of Business Economics and Management, 21(4), 1072-1092. https://doi.org/10.3846/jbem.2020.12274

Bencikova, D., Mala, D., \& Minarova, M. (2013). How culturally intelligent are Slovak small and medium business? 7th International Days of Statistics and Economics, 109-121

Borocki, J., Radisic, M., Sroka, W., Greblikaite, J., \& Androniceanu, A. (2019). Methodology for strategic posture determination of SMEs - the case from a developing country. Inžinerine Ekonomika-Engineering Economics, 30(3), 265-277.

Chrenekova, M., Melichova, K., Marisova, E., \& Moroz, S. (2016). Informal employment and quality of life in rural areas of Ukraine. European countryside, 8(2), 135-146, SI. https://doi.org/10.1515/euco-2016-0011

Çera, G. Meço, M., Çera, E., \& Maloku, S. (2019). The effect of institutional constraints and business network on trust in government: an institutional perspective. Administratie si Management Public, 33, 6-19, https://doi.org/10.24818/amp/2019.33-01

Cibik, L., \& Melus, M. (2019). Fiscal Decentralization in the Slovak Republic: Revenues and Expenditures. Lex localis-Journal of local self-government, 17 (3), 697-720. https://doi.org/10.4335/17.3.697-720(2019) 


\section{ENTREPRENEURSHIP AND SUSTAINABILITY ISSUES}

ISSN 2345-0282 (online) http://jssidoi.org/jesi/

2021 Volume 8 Number 3 (March)

http://doi.org/10.9770/jesi.2021.8.3(31)

Make your research more visible, join the Twitter account of ENTREPRENEURSHIP AND SUSTAINABILITY ISSUES: @ Entrepr69728810

Cooper, D. J., Ezzamel, M., \& Qu, S. Q. (2017). Popularizing a management accounting idea: The case of the balanced scorecard. Contemporary Accounting Research, 34(2), 991-1025. https://doi.org/10.1111/1911-3846.12299

Cepel, M., Dvorsky, J., Gregova, E., \& Vrbka, J. (2020). Business environment quality model in the SME segment. Transformations in Business \& Economics, 19(1), 262-283.

Csikosova, A., \& Culkova, K. (2012). Industrial marketing as review of opinion and realization problems. Acta Montanistica Slovaca, 17 (3), 167-173.

Cvetanovič, D. Despotovič. (2014). Knowledge as the component of human capital in economic growth models. Škola biznisa, 1, 1-17.

Doležal, T. et al., (2000). Integration of sustainability development principles into tourism. Praha: Charles University, Faculty of Physical Education and Sport

Dvorský, J., Petráková, Z., \& Polách, J. (2019). Assessing the Market, Financial, and Economic Risk Sources by Czech and Slovak SMEs. International Journal of Entrepreneurial Knowledge, 7(2), 30-40. https://doi.org/10.12345-000

Dvorský, J., Petráková, Z., Ajaz Khan, K., Formánek, I., \& Mikoláš, Z. (2020). Selected Aspects of Strategic Management in the Service Sector. Journal of Tourism and Services, 20(11), 109-123. https://doi.org/10.29036/jots.v11i20.146

Durda, L., \& Kljucnikov, A. (2019). Social networks in entrepreneurial startups development. Economics \& Sociology, 12(3), 192-208. https://doi.org/10.14254/2071-789X.2019/12-3/13

Dyduch, W. (2019). Entrepreneurial Strategy Stimulating Value Creation: Conceptual Findings and Some Empirical Tests. Entrepreneurial Business and Economics Review, 7(3), 65-82. https://doi.org/10.15678/EBER.2019.070304

European Commission. (2016a). Annual report on European SMEs 2015/2016. Retrieved from http://ec.europa.eu/growth/smes/businessfriendly-environment/performance-review-2016_ro

European Commission. (2016b). Funds absorption rate. Retrieved from https://cohesiondata.ec.europa.eu/dataset/2007-2013-FundsAbsoption-Rate/kk86-ceun

European Commission. (2017). Value added at factor costs (\% of total value added by enterprises). Retrieved from https://ec.europa.eu/growth/smes/business-friendly-environment/performance-review-2016_ro

Fernandes, F. D. S., Stasinakis, C., \& Bardarova, V. (2018). Two-stage DEA-Truncated Regression: Application in banking efficiency and financial development. Expert Systems with Applications, 96, 284-301, https://doi.org/10.1016/j.eswa.2017.12.010

Grasseová, M., Dubec, R., \& Řehák, D. (2012). Analýza podniku v rukou manažera. 33 nejpouživanějšich metod strategického řizení (Business analysis in the hands of a manager. 33 most used methods of strategic management). 2. vydání. Brno: BizBooks, 2012. 325 s. ISBN 978-80-265-0032-2

Gupta, V. K., \& Batra, S. (2016). Entrepreneurial orientation and firm performance in Indian SMEs: Universal and contingency perspectives. International Small Business Journal: Researching Entrepreneurship, 34(5), 660-682. https://doi.org/10.1177/0266242615577708

Haber, S., Reichel, A. (2005). Identifying Performance Measures of Small Ventures-The Case of the Tourism Industry. Journal of Small Business Management, 43(30), 257-286. https://doi.org/10.1111/j.1540-627X.2005.00137.x

Harabi, N. (2005). Determinants of Firm Growth: An Empirical Analysis from Morocco. MPRA Paper, Switzerland: University of Applied Sciences, https://mpra.ub.uni-muenchen.de/4394/1/MPRA_paper_4394.pdf

Haviernikova, K., Kordos, M. \& Navickas, V. (2018). The motivation of Slovak small and medium entrepreneurs towards cluster cooperation. Transformations in Business \& Economics, 17(3), 91-101 


\section{ENTREPRENEURSHIP AND SUSTAINABILITY ISSUES}

ISSN 2345-0282 (online) http://jssidoi.org/jesi/

2021 Volume 8 Number 3 (March)

http://doi.org/10.9770/jesi.2021.8.3(31)

Make your research more visible, join the Twitter account of ENTREPRENEURSHIP AND SUSTAINABILITY ISSUES: @Entrepr69728810

Haviernikova, K., Snieska, V., Navickas, V., \& Burksaitiene, D. (2019). The attitudes of small and medium entrepreneurs toward cluster cooperation: the expectations and reality. Transformations in Business \& Economics, 18 (3), 191-205.

Horvath, P., \& Machyniak, J. (2016). Media impact on public policy making. Marketing identity: brands we love, PT I. International Scientific Conference on Marketing Identity 2016: Brands We Love, 316-325

Hudáková, J. Fil’a, M., \& Maroš, M. (2017). Innovation potential of the regions in the Slovak republic. Acta Oeconomica Universitatis Selye 6 (2), $81-88$.

Hudáková, M., \& Masár, M. (2018). Assessment of the Key Business Risks of the SMEs in Slovakia and Their Comparison with other EU Countries. Entrepreneurial Business and Economics Review, 6(4), 145-160. https://doi.org/10.15678/EBER.2018.060408

Huggins, R., \& Thompson, P., (2015). Entrepreneurship, innovation and regional growth: a network theory. Small Business Economics, 45(1), 103-128.

Charnes, A., Clark, C. T., Cooper, W. W., \& Golany, B. A (1984). Developmental study of data envelopment analysis in measuring the efficiency of maintenance units in the U.S. air forces. Annals of Operations Research, 2, 95-112, https://doi.org/10.1007/BF01874734

Chehabeddine, M., \& Tvaronavičienè, M. (2020). Securing regional development. Insights into Regional Development, 2(1), 430-442. https://doi.org/10.9770/IRD.2020.2.1(3)

Chunling Li, Khansa Pervaiz, Muhammad Asif Khan, Faheem Ur Rehman, \& Oláh, J. (2019). On the Asymmetries of Sovereign Credit Rating Announcements and Financial Market Development in the European Region. Sustainability, 11(23), 6636, 1-14. https://doi.org/10.3390/su11236636

Dellis, K., Karkalakos, S., \& Kottaridi, C. (2016). Entrepreneurship Targeting Policies, Technological Growth, and Unemployment. Journal of Eurasian Economic Dialogue, 1(6), 19-39.

Janoskova, M., Culkova, K., \& Csikosova, A. (2018). Position and development of small and medium enterprises in european countries. Proceedings of the 8th Business \& Management Conference. Proceedings of the Business \& Management Conferences, 91-103. https://doi.org/10.20472/BMC.2018.008.007

Jašková, D. (2019). Assessment of social development in Slovakia in the context of human resources. Central European Journal of Labour Law and Personnel Management, 2 (2), 21-32. https://doi.org/10.33382/cejllpm.2019.03.02

Kordos, M. (2018). Risk aspect of cluster innovation potential in SR and EU. International relations 2018: Current issues of world economy and politics. 19th International Scientific Conference on International Relations - Current Issues of World Economy and Politics, 345-358

Kotaskova, A., \& Rozsa, Z. (2018). The impact of selected factors on the quality of business environment assessment in the Czech Republic and the Slovak Republic. International Journal of Entrepreneurial Knowledge, 6(2), 71-80. https://doi.org/10.2478/IJEK-2018$\underline{0015}$

Kotulic, R., Adamisin, P., Vozarova, I.K., \& Vavrek, R. (2017). Targeted regionalization of Slovakia to ensure economic efficiency and sustainability of agriculture. 20th International Colloquium on Regional Sciences, 185-192. https://doi.org/10.5817/CZ.MUNI.P210-8587$\underline{2017-23}$

Kozubíková, L., \& Kotásková, A. (2019). The impact of technological factors on the quality of the business environment. Transformations in Business \& Economics, 18(1), 95-108.

Lakner, Z., Kiss, A., Merlet, I., Oláh, J., Máté, D., Grabara, J., \& Popp, J. (2018). Building Coalitions for a Diversified and Sustainable Tourism: Two Case Studies from Hungary. Sustainability, 10, 1090.

Lazikova, J., Bandlerova, A., Rohacikova, O., Schwarcz, P., \& Rumanovska, L. (2018). Regional Disparities of Small and Medium Enterprises in Slovakia. Acta Polytechnica Hungarica, 15 (8), 227-246. https://doi.org/10.12700/APH.15.8.2018.8.12 


\section{ENTREPRENEURSHIP AND SUSTAINABILITY ISSUES}

ISSN 2345-0282 (online) http://jssidoi.org/jesi/

2021 Volume 8 Number 3 (March)

http://doi.org/10.9770/jesi.2021.8.3(31)

Make your research more visible, join the Twitter account of ENTREPRENEURSHIP AND SUSTAINABILITY ISSUES: @ Entrepr69728810

Mardani, A.; Zavadskas, E. K.; Streimikiene, D.; Jusoh, A.; \& Khoshnoudi, M. (2017). A comprehensive review of data envelopment analysis (DEA) approach in energy efficiency. Renew. Sustain. Energy Rev. 70, 1298-1322, https://doi.org/10.1016/j.rser.2016.12.030

Meyer, N., \& Kot, S. (2019). Entrepreneurial motivation: a cross country comparison between Polish and South african students. Transformations in Business \& Economics, 18(3), 155-167.

Mikhaylova, A. A., Mikhaylov, A. S., Savchina, O. V., \& Plotnikova, A. P. (2019). Innovation landscape of the Baltic region. Administratie si Management Public, 33, 165-180, https://doi.org/10.24818/amp/2019.33-10

Peracek, T. (2019). Family Business and Its Anchoring In the Legal Order of the Slovak Republic and the Czech Republic. 33rd International-Business-Information-Management-Association (IBIMA) Conference. Education excellence and innovation management through Vision 2020, 7290-7298

Peracek, T., Noskova, M., \& Mucha, B. (2017). Special characters of family businesses in the Slovak republic. International Scientific Conference on Economic and Social Development. Economic and social development (esd): managerial issues in modern business, 260266.

Pisar, P., \& Bilkova, D. (2019). Controlling as a tool for SME management with an emphasis on innovations in the context of Industry 4.0. Equilibrium. Quarterly Journal of Economics and Economic Policy, 14(4), 763-785. https://doi.org/10.24136/eq.2019.035

Poór, J., Engle, A.D., Kovács, Á., Albrychiewicz-Slocinska, A., Caha, Z., Kumpikaite-Valiuniene, V., \& Horbulák, Zs. (2020). Initial findings for labour markets in the Czech Republic, Hungary, Poland and Slovakia. Central European Journal of Labour Law and Personnel Management, 3(1), 46-59. https://doi.org/10.33382/cejllpm.2020.04.04

Pratheepan, T. 2014. A panel data analysis of profitability determinants: Empirical results from Sri Lankan manufacturing companies. International Journal of Economics, Commerce and Management, 2(12), 1-9.

Raisová, M., Regásková, M., \& Lazányi, K. (2020). The financial transaction tax: an ANOVA assessment of selected EU countries. Equilibrium. Quarterly Journal of Economics and Economic Policy, 15(1), 29-48. https://doi.org/10.24136/eq.2020.002

Ramanathan, R., \& Ramanathan, U. (2011). A performance measurement framework combining DEA and balanced scorecard for the UK health sector. International Journal of Operational Research, 12(3), 257-278.

Remeikiene, R., Belas, J., Kliestik, T., \& Smrcka, L. (2020). Quantitative assessment of dynamics of economic development in the countries of the European Union. Technological and Economic Development of Economy, 26(4), 933-946. https://doi.org/10.3846/tede.2020.12892

Selivanova-Fyodorova, N., Komarova, V, Lonska, J., \& Mietule, I. (2019). Differentiation of internal regions in the EU countries. Insights into Regional Development, 1(4), 370-384. https://doi.org/10.9770/ird.2019.1.4(7)

Sheehan, M. (2013). Human resource management and performance: Evidence from small and medium-sized firms. International Small Business Journal: Researching Entrepreneurship, 32(5), 545-570. https://doi.org/10.1177/0266242612465454

Simar, L., \& Wilson, P. W.(2007). Estimation and inference in two-stage, semi-parametric models of production processes. Journal of Economics, 136, 31-64, https://doi.org/10.1016/j.jeconom.2005.07.009

Tamulevičienè, D., \& Androniceanu, A. (2020). Selection of the indicators to measure an enterprise's value and its changes in the controlling system for medium-sized enterprises. Entrepreneurship and Sustainability Issues, 7(3), 1440-1458. https://doi.org/10.9770/jesi.2020.7.3(1)

Tingvall, P. G., \& Videnord, J. (2018). Regional differences in effects of publicly sponsored R\&D grants on SME performance. Small Business Economics, 54, 951-969. https://doi.org/10.1007/s11187018-0085-6 


\section{ENTREPRENEURSHIP AND SUSTAINABILITY ISSUES}

ISSN 2345-0282 (online) http://jssidoi.org/jesi/

2021 Volume 8 Number 3 (March)

http://doi.org/10.9770/jesi.2021.8.3(31)

Make your research more visible, join the Twitter account of ENTREPRENEURSHIP AND SUSTAINABILITY ISSUES: @Entrepr69728810

Tsai, W.H.; Lee, H.L.; Yang, C.-H.; \& Huang, C.-C. (2016). Input-Output Analysis for Sustainability by Using DEA Method: A Comparison Study between European and Asian Countries. Sustainability 8, 1230, https://doi.org/10.3390/su8121230

Vekic, A., Djakovic, V., Borocki, J., Sroka, W., Popp, J., \& Olàh, J. (2020). The Importance of Academic New Ventures for Sustainable Regional Development. Amfiteatru Economic, 22(54), 533-550.

Virglerová, Z., Homolka, L., Smrcka, L., Lazányi, K., \& Klieštik, T. (2017). Key determinants of the quality of business environment of SMEs in the Czech Republic. E \& M Ekonomie a Management, 20 (2), 87-101. https://doi.org/10.15240/tul/001/2017-2-007

Wallsten, S. J. (2000). The Effects of Government-Industry R\&D Programs on Private R\&D: The Case of the Small Business Innovation Research Program. The Rand Journal of Economics, 31(1), 82-100.

Wei, C.-K., Chen, L.-C., Li, R.-K., Tsai, C.-H., \& Huang, H.-L. (2012). A study of optimal weights of Data Envelopment Analysis Development of a context-dependent DEA-R model. Expert Systems with Applications. 39 (4), 4599-4608.

Wernerfelt, B. 1984. A resource-based view of the firm. In: Strategic Management Journal, roč. 5, č. 2, s. 171-180. ISSN 1097-0266.

Zavadska, Z., \& Zavadsky, J. (2020). Quality managers and their future technological expectations related to Industry 4.0. Total Quality Management \& Business Excellence, 31 (7-8), 717-741. https://doi.org/10.1080/14783363.2018.1444474

Zauskova, A., \& Reznickova, M. (2020). SoLoMo marketing as a global tool for enhancing awareness of eco-innovations in Slovak business environment. Equilibrium. Quarterly Journal of Economics and Economic Policy, 15(1), 133-150. https://doi.org/10.24136/eq.2020.007

\section{Acknowledgements}

This research was supported by the project VEGA 1/0813/19 Managing the development of innovative and start-up forms of businesses in international environment and verification of INMARK concept, which has received funding from Ministry of Education, Science, Research and Sport of the Slovak Republic and project GAAA 5-5/2020 Development of family businesses in Slovak regions, which has received funding from Grant Agency Academia aurea, VEGA 1/0240/20. 


\section{ENTREPRENEURSHIP AND SUSTAINABILITY ISSUES}

ISSN 2345-0282 (online) http://jssidoi.org/jesi/

2021 Volume 8 Number 3 (March)

http://doi.org/10.9770/jesi.2021.8.3(31)

Make your research more visible, join the Twitter account of ENTREPRENEURSHIP AND SUSTAINABILITY ISSUES: @Entrepr69728810

Ladislav MURA is an Associate Professor, a Slovak expert on small and medium business, international business, and the human resource of management. He is the author of 3 domestic scientific monographs on the internationalization of business, small and medium enterprises, human resource management, co-author of foreign scientific monographs. He has published a lot of articles in various scientific journals.

ORCID ID: https://orcid.org/0000-0002-2453-8740

Zuzana HAJDUOVÁ is an expert in assessing performance and efficiency in service enterprises specialized in business informatics and linear programming. In addition, she is devoted to the application of the DEA method to measure the effectiveness of small and medium business, as confirmed by her scientific outputs registered in the WoS and Scopus databases.

ORCID: https://orcid.org/0000-0002-9381-776X

Copyright (C) 2021 by author(s) and VsI Entrepreneurship and Sustainability Center

This work is licensed under the Creative Commons Attribution International License (CC BY).

http://creativecommons.org/licenses/by/4.0/

c) (†) Open Access 